\title{
Effectiveness of cadre empowerment toward the coverage of stimulation, detection and intervention of early development children
}

\author{
Retno Puji Hastuti ${ }^{1}$, Fitarina ${ }^{2}$ \\ ${ }^{1,2}$ Kotabumi Nursing Program Study, Tanjungkarang Health Polytechnic, Indonesia
}

\begin{tabular}{l}
\hline \hline ARTICLE INFO \\
\hline Article history: \\
Received: August 9, 2020 \\
Revised: August 20, 2020 \\
Accepted: August 30, 2020 \\
\hline
\end{tabular}

\section{Keywords:}

Empowerment Cadre; SDIDTK, todlers

\begin{abstract}
Stunting cases in North Lampung continuously increase due to lack of visits by mothers to perform stimulation, detection, early intervention for toddler development (SDIDTK). This study aims to determine the effectiveness of cadre empowerment on SDIDTK completion among children under five. The intervention of SDIDTK training for 50 cadres. The study used a Quasiexperimental Pre and Post-Test Design without control. Univariate data analysis with proportion, average, and standard deviation. Bivariate analysis using the Wilcoxon-test and Pearson Chi-Square Test. The results showed that there was a significant difference in the average score of knowledge of the cadres before and after the empowerment of cadres ( $\mathrm{p}$-value $=0.000$ ). There was a significant correlation between cadre empowerment and the measurement completion of height, head circumference, and measurement of development $(\mathrm{p}$-value $=0.000)$, however, there is no significant relationship between cadre empowerment and the completion of body weight measurement ( $p$-value $=0.317)$. Suggestions for Health workers and health offices to carry out training on SDIDTK to all cadres, to provide guidance and motivation, and to provide SDIDTK facilities and infrastructure at Posyandu.
\end{abstract}

This work is licensed under a Creative Commons Attribution 4.0 International License.

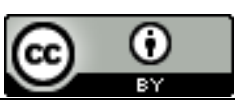

\section{Corresponding Author:}

Retno Puji Hastuti,

Kotabumi Nursing Program Study,

TanjungkarangHealth Polytechnic,

SoekarnoHatta Street No. 6, Bandar Lampung

Email: retnopujihastuti15@gmail.com

\section{INTRODUCTION}

Toddlers are an important phase for child development, in which they learn to recognize various kinds of facts from the environment as a stimulant for their growth and development [1]. One of the efforts to comprehensively improve the quality of children's development is SDIDTK activities which consist of: Measuring height and body weight activities to determine the nutritional status; Measurement of head circumference to detect micro or macrocephaly; and development screening to determine the development status (fine motor skills, gross motor skills, language, socialization and independence). SDIDTK activities should be carried out in a comprehensive and coordinated manner and be held in the form of partnerships between families, communities and professional staff [2]. Based on 2014 Public Health Development Index (IPKM) data, the completion of visiting to posyandu for SDIDTK in Lampung was only 53.05\%. This precentage is lower than the national precentage which was $68.28 \%$. This condition is one of the causes of the high rate of stunting in Lampung [3]. Based on Riskesdas 2018, Indonesia's stunting rate is 30.8\%, where Indonesia is ranked as the 5th country with the highest stunting rate in the world. While stunting rate in Lampung Province reached $42.6 \%$ and in 2018 it became $27.28 \%$. Stunting is short stature caused by longterm malnutrition or chronic malnutrition caused by inadequate nutritional intake or increased nutritional needs due to suboptimal health conditions due to disease [4].

Research by Morrison et al. States that in low-income and middle-income countries, it is estimated that one of three preschool children has a developmental disorder. Developmental screening programs are 
hampered by the low attendance of mothers under five to check for continued development after initial screening. The high workload of health workers at the clinic causes them not to carry out examinations for the growth and development of children under five. Mother or nanny generally also does not understand the results of toddler growth and development tests and how to stimulate child development [5].

Stunting is one of the health problems in maternal and child health services in North Lampung. The prevalence of nutritional status (TB/U) in children 0-59 months (toddlers) by regency/city in North Lampung Province was $8.44 \%$ very low, $18.20 \%$ low, and $65.64 \%$ normal. The prevalence of nutritional status (BB/U) was $3.08 \%$ very poor nutrition, $12.30 \%$ poor nutrition, $78.50 \%$ good nutrition and $6.12 \%$ over nutrition. The proportion number of growth monitoring in North Lampung district in the last 12 months in children aged 059 months according to Kota Regency in Lampung Province was $81.29 \%$ and PB/TB monitoring was $17.68 \%$.

Data from the North Lampung District Health Office in 2018 the coverage of under-five weighing or visits to Posyandu was $32 \%$, this figure is lower than the coverage figure of Lampung Province which was $53.05 \%$ and national $68.28 \%$. One of the causes of the high number of stunting according to Indonesian Minister of Health was the low number of visits of mothers of children under five to Posnyandu. Mostly mother of a toddler was no longer carry her toddler to the Integrated Healthcare Centre after completing basic immunization in the first year.

According to Morrison, et al. Challenges in implementing SDIDTK were the limited knowledge of mothers of children under five, caregivers and cadres, and the high workload of health workers at Posyandu. Empowerment of cadre participation in SDIDTK implementation is urgently needed at Posyandu. Empowerment of cadres needs to be carried out through cadre training which can increase cadres' knowledge and skills in implementing SDIDTK. Among them are optimizing SDIDTK services that have not been implemented, such as measuring height and head circumference at table 2, and development detection and stimulation services used KIA Books at table 4 at posyandu. Based on the description above, the authors are interested in conducting research on "The Effectiveness of Cadre Empowerment on the Coverage of SDIDTK for Toddlers in North Lampung".

\section{RESEARCH METHOD}

2.1 Method

This research is qualitative research with a Quasi-experimental with pre and post-test Design Without Control. The interventions were in the form of empowering cadres through SDIDTK toddlers' training activities and facilitating SDIDTK equipment in Posyandu: Head circumference measuring tape, height, or body length gauges (Microtoa) and SDIDTK kits [6].

\subsection{Research location and place}

The research was carried out at one posyandu in the working area of Puskemas Kotabumi 1, Kotabumi

2, Kotabumi Udik, Semuli Raya, Kali Balangan, Blambangan Pagar, Wonogiri, Pekurun, Madukoro, and Puskesmas Abung Kunang in September - October 2019.

\subsection{Population and Sample}

The Population of this study was all cadres in the northern Lampung region as 632 people. The research sample was calculated using The Correlative analytical research formula. Type I error was set at $5 \%$, the hypothesis is one-way so that $Z=1.64$. Type II error is set at $10 \%$, then $Z=1.28$. The minimum correlation which is considered significant ( $\mathrm{r}$ is set at 0.4 so that the sample size is 50 people [7]. As many as 50 cadres from 10 working areas of the North Lampung subdistrict health center were taken by the Consecutive-sampling technique. The sample criteria are cadres with high school education and at least have become cadres for one year.

\subsection{Data collection}

Data collection by interview and observation method using cadre knowledge questionnaire about SDIDTK and observation sheet of SDIDTK implementation in Posyandu. The tools used in the study were the Toddler SDIDTK Training Module for cadres, BB Scales, Body Length/Height Measurements (Microtoa), head circumference measuring tape, SDIDTK Kit, and KIA Handbook.

\subsection{Data Analyzed}

Data analyzed with Univariate data analysis, there are proportions, mean, and Standard Deviation (SD) cadre knowledge. Bivariate analysis to analyze the differences in the average score of knowledge with the Wilcoxon test and Pearson Chi-Square Test was used to determine the relationship of cadre empowerment with SDIDTK coverage. 


\section{RESULTS AND DISCUSSIONS}

\subsection{Facilities and infrastructure}

The result of research Facilities and infrastructure of SDIDTK in 10 Posyandu in North Lampung, those were: 100\% Posyandu has weight gauges (Dacin); 10\% have head circumference measuring tape, $20 \%$ The Integrated Healthcare Centre have Body Length/Height Measuring instruments; 10\% The Integrated Healthcare Centre is the building itself; $70 \%$ of children under five have an $\mathrm{MCH}$ book; There are no Integrated Healthcare Centre that has SDIDTK KIT (0\%); 100\% Integrated Healthcare Centre has SDIDTK reporting books, but the form was still varied.

In this study, it was found that SDIDTK activities at Posyandu in the North Lampung had not been implemented optimally, especially in measuring body height/length, head circumference, and detection of development due to unavailability of measuring instruments. According to Notoatmodjo, the realization of action not only requires knowledge and a positive attitude towards an object but also supported by facilities or infrastructure [8]. This standard of equipment is very important to get valid measurement results. The affecting factor toward negative attitudes of the cadres in SDIDTK activities at the posyandu was incomplete facilities $(\mathrm{p}=0.001)$. It is hoped that health workers will provide full support to posyandu cadres through training and provision of facilities [9]

\subsection{Empowerment of cadres through SDIDTK training}

There were three main components that play a role in the successful achievement of the nutrition program, namely community participation (cadres and community leaders), participation of health center officers, and the role of other sectors. Of the three components, the community participation component will determine the success of the posyandu. Some of the factors causing the low achievement of the nutritional status program at the posyandu, one of which was the lack of community knowledge about the importance of nutrition [10]. Community empowerment in the health sector is an effort for community independence to organize non-governmental organizations to tackle disease risk factors which include promotive, preventive, curative and rehabilitative efforts, as well as collecting health contributions Community empowerment is generally in the form of health education, namely all efforts that are planned to influence other people, both individuals, groups, and communities so that they do what the health worker expects [11].

The Empowerment of cadres in this research is by facilitating SDIDTK training. The aim of this training is to enable cadres to implement SDIDTK at posyandu, including detection of toddler growth by measuring body weight, height and head circumference. Stimulation, detection, and early intervention for toddler development using the KIA handbook. The training was attended by 50 people and 10 health workers who acted as facilitators. The implementation of the activity includes several stages, namely the preparation stage, pre-test, material provision, discussion and question and answer, demonstration and redemption, posttest implementation, and closing.

In this training, three presenters were given explanations, those were about the introduction of child development: understanding of toddler growth and development, affecting factors toward toddler development; Growth monitoring; and monitoring the development of children under five with the KIA book. After training the cadres are expected to have a good and correct understanding and attitude about SDIDTK. During the training, cadres were also given demonstrations, and cadres were asked to re-demonstrate SDIDTK procedures according to Standard Operational Procedures (SOPs) by using standard facilities and infrastructure. In this training, all material is presented in the training module. The changes in cadres' knowledge before and after SDIDTK training were:

Table 1. Knowledge of cadres about SDIDTK before and after the SDIDTK Training in North Lampung in 2019

\begin{tabular}{lccccc}
\hline $\begin{array}{c}\text { Knowledges } \\
\text { about } \\
\text { SDIDTK }\end{array}$ & Average & SD & Min & Max & p-value \\
\hline Pre & 7,44 & $\pm 1,03$ & 5,00 & 9,00 & 0,00 \\
Post & 7,68 & $\pm 0,926$ & 6,00 & 9,00 & \\
\hline
\end{tabular}

From table 1. There was an increase in the average cadre knowledge of SDIDTK from 7.44 to 8.68 , there were differences in the average value of cadre knowledge before and after training ( $p$-value $=0,000$ ). In this study, knowledge about SDIDTK before training, the average score of knowledge of cadres was 7.437 ( \pm 1.03) on a scale of $0-10$, while after the SDIDTK training the average score of cadres' knowledge increased to $7.68( \pm 0.926)$ or an increase of 0.24 points. There was a significant difference in the average score of cadres' 
knowledge of SDIDTK before and after training ( $\mathrm{p}$-value $=0.000)$. From the research results, it was found that before training the cadres generally had good knowledge and got better after attending SDIDTK training.

Health education is expected to change health attitudes and behavior. Health behavior is a complex phenomenon and has a very wide range. Behavior is divided into three domains, namely knowledge, attitudes, and psycho-root. Knowledge is the result of human sensing or knowing about an object which is affected by the intensity of one's attention and perception of an object. Knowledge is a predisposing factor that affects attitudes and psychomotor. Health behavior is influenced by internal factors (perception, knowledge, belief, desire, motivation, intention and attitude) and external factors (facilities, infrastructure, reward/punishment, and socio-culture) [12].

The limited number of health personnel and a large number of children under five as targets require the participation of cadres in the implementation of SDIDTK. In order for cadres to be actively involved in the implementation of SDIDTK, it is necessary to increase the knowledge and skills of cadres in implementing SDIDTK [13]. One of the ways to empower cadres is through training. Adequate knowledge of cadres about SDIDTK is expected to increase the active participation and confidence of cadres in implementing SDIDTK for toddlers. In addition, cadres are part of the health service system closest to mothers of toddlers, so that they are expected to motivate mothers to increase toddler visits to posyandu to implement SDIDTK. One of the roles of cadres at posyandu is an extension agent to motivate the community to participate in Posyandu activities in their area. Cadres have a very important role, especially in motivating mothers of toddlers to visit Posyandu and implementing the SDIDTK program [14].

Community Development Programs can only be sustainable if the community itself owns and manages the activities. Community empowerment is an effort to prepare the community by strengthening community institutions so that the community is able to achieve independence and sustainable social welfare. The benefits of empowerment in the future are the creation of a long-term, sustainable increase in welfare, an increase in the use of development resources effectively and efficiently; and more effective, efficient SDIDTK services. In addition, cooperation with parents to monitor children's growth and development is an important component of children's health service [15]. Next Family during the early years, especially parenting, expected stimulation for lifetime skill development formed before children enter formal schooling [16].

\subsection{SDIDTK coverage}

In this study, the effectiveness of cadre empowerment was examined for SDIDTK coverage, including measurement coverage of height/body length, body weight, head circumference, and early detection stimulation for toddler development and development using the KIA book for toddlers as follows:

Table 2.The Effect of Cadre Empowerment on the completion of Body Height/Length Measurement in Posyandu in the North Lampung

\begin{tabular}{lcccc}
\hline \multirow{2}{*}{ Cadre Empowerment } & \multicolumn{2}{c}{$\begin{array}{c}\text { Body Height /Length } \\
\text { Measurement }\end{array}$} & \multirow{2}{*}{ Total } & p-value \\
\cline { 2 - 3 } & Done & No & & \\
\hline Pre & 81 & 196 & 277 & 0,000 \\
& $29.2 \%$ & $70.8 \%$ & $100.0 \%$ & \\
Post & 210 & 67 & 277 & \\
Total & $75.8 \%$ & $24.2 \%$ & $100.0 \%$ & \\
\hline
\end{tabular}

There was an increase in Body Height/length measurement completion from $29.2 \%$ to $75.8 \%$ and there was a significant relationship between cadre empowerment and TB measurement coverage $(\mathrm{p}=0,000)$;

Table 3. The Effect of Cadre Empowerment on the Coverage of Measurement of Body Weight at Posyandu in Kotabumi Utara Working Area

\begin{tabular}{lcccc}
\hline \multirow{2}{*}{ Cadre Empowerment } & \multicolumn{2}{c}{ Body Weight Measurement } & \multirow{2}{*}{ Total } & \multirow{2}{*}{ p-value } \\
\cline { 2 - 3 } & Done & No & & \\
\hline Pre & 276 & 1 & 277 & 0,317 \\
& $99.6 \%$ & $0.4 \%$ & $100.0 \%$ & \\
Post & 277 & 0 & 277 & \\
Total & $100.0 \%$ & $0.0 \%$ & $100.0 \%$ & \\
\hline
\end{tabular}

An increase in body weight measurement from $99.6 \%$ to $100 \%$, but there was no significant relationship between cadre empowerment and BB measurement coverage $(\mathrm{p}$-value $=0.317)$. 
Table 4. The Effect of Cadre Empowerment on the Coverage of Measurement of Head Circumference at Posyandu in the North Kotabumi Working Area

\begin{tabular}{lcccc}
\hline Cadre & \multicolumn{2}{c}{ Body Weight Measurement } & \multirow{2}{*}{ Total } & \multirow{2}{*}{ p-value } \\
Empowerment & Done & No & 277 & \multirow{2}{*}{0,317} \\
Pre & 276 & 1 & $100.0 \%$ & \\
Post & $99.6 \%$ & $0.4 \%$ & 277 & \\
Total & 277 & 0 & $100.0 \%$ & \\
\hline
\end{tabular}

An increase in the coverage of head circumference measurements from $18.1 \%$ to $50.9 \%$ and there is a relationship between the empowerment of cadres and the measurement of head circumference $(p=0,000)$;

Table 5. the Effect of Cadre Empowerment on the Scope of Detection of Toddler Development in Posyandu in North Kotabumi Working Area

\begin{tabular}{|c|c|c|c|c|}
\hline \multirow{2}{*}{$\begin{array}{l}\text { Cadre } \\
\text { Empowerment }\end{array}$} & \multicolumn{2}{|c|}{ Body Height /Length Measurement } & \multirow[b]{2}{*}{ Total } & \multirow[b]{2}{*}{ p-value } \\
\hline & Done & No & & \\
\hline \multirow[t]{2}{*}{ Pre } & 1 & 276 & 277 & 0,000 \\
\hline & $0.4 \%$ & $99.6 \%$ & $100.0 \%$ & \\
\hline Post & 86 & 191 & 277 & \\
\hline Total & $31.0 \%$ & $69.0 \%$ & $100.0 \%$ & \\
\hline
\end{tabular}

There was an increase in development, from $0,4 \%$ to $31,0 \%$, and the relationship between cadre empowerment and the scope of measurement of toddler development $(p=0,000)$. The effectiveness of SDIDTK coverage in this study is an increase in SDIDTK coverage including growth detection (measuring $\mathrm{TB}$, weight, LK) and development of children under five using the KIA book. Prior to training, cadres generally only weighed at table 2 at the posyandu. This happened because the facilities and infrastructure for implementing SDIDTK were not yet available at Posyandu. After the training, the posyandu service activities in the following month saw an increase in SDIDTK coverage, especially measurements of height/length, head circumference, and development $(\mathrm{p}=0.000)$.

Monitoring Weight/age indicator can be seen in the KIA / KMS book, where this indicator is a monitoring of whether a child is growing well or not (failure to thrive). Head circumference can be divided into normal, small (microcephaly), and large (macrocephaly). Small or large head circumference can be caused by impaired brain growth [17]. According to Notoatmodjo, to realize an action not only requires knowledge and a positive attitude towards an object but also is supported by facilities or infrastructure [18]. It is very important to monitor the growth measurement of children under five to detect any growth problems in children. The WHO Global Database on Child Growth and Malnutrition compiles data on height-for-age, weight-forage, and weight-for-height of preschool children worldwide to monitor in combating childhood malnutrition [19]

Of all posyandu SDIDTK activities, the coverage that was still relatively low after the training was the detection and stimulation of the development of children under five with the KIA handbook, from $0.4 \%$ to $31.0 \%$. This is because the cadres are still adapting to changes in their previous routine. According to Notoatmodjo, the practice of a skill in an individual will occur gradually. Psychomotor skills are divided into three stages according to their quality, those are guided practice, mechanism practice, and adoption. In guided practice, someone will do something depending on the demands or use a guide. Cadres are still waiting to be reminded by the health personnel in charge to implement SDIDTK in Posyandu activities. Furthermore, cadres can carry out SDIDTK automatically without waiting for orders (mechanical practice). Furthermore, cadres are expected to be able to develop SDIDTK services at Posyandu (Adoption). For this reason, the role of health workers is needed to provide supervision, motivation, and as a place of reference for cadres in implementing SDIDTK.

\section{CONCLUSION}

Effective cadre empowerment to increase SDIDTK completion at posyandu in North Lampung. North Lampung health service is expected to conduct SDIDTK training to all health workers and Integrated Healthcare Centre cadres. It also provides guidance and motivation, as well as providing SDIDTK facilities and infrastructure throughout the posyandu in North Lampung. 


\section{Acknowledgments}

Best gratitude are addressed to the Director of Poltekkes Tanjung karang who has funded this research. Acknowledgments are also adressed to the Head of the North Lampung District Health Office for facilitating this research.

\section{REFERENCES}

[1] Kementerian Kesehatan RI, "PedomanPelaksanaan SDIDTK di Tingkat Pelayanan Dasar," 2016.

[2] H. Mulcahy and E. Savage, "Uncertainty: A little bit not sure. Parental concern about child growth or development," Journal Child Heal Care, vol. 20, no. 3, p. 333-343, 2016.

[3] J. Morrison, I. Chunsuwan, P. Bunnag and P. C. Gronho, "Thailand 's national universal developmental screening program for young children: action research for improved follow-up," p. 1$11,2018$.

[4] Riskesdas, "Laporan Provinsi Lampung:Pedoman Pelaksanaan SDIDTKA," Kementerian Kesehatan RI, 2016.

[5] D. Roykhana and B. T. Husodo, "Faktor-Faktor Yang Berhubungan Dengan Evaluasi Program Deteksi Dini Tumbuh Kembang Balita Di Taman Posyandu Puskesmas Lamongan," Journal Kesehatan Masyarakat, vol. 6, no. 1, pp. 724-733,, 2018.

[6] Jumiyati, Nugrahaeni and A. Margawati, "Pengaruh Modul Terhadap Peningkatan Pengetahuan, Sikap Dan Praktek Kader Dalam Upaya Pemberian Asi Eksklusif," Gizi Indonesia, vol. 31, no. 1, p. 19-28, 2014.

[7] S. Dahlan, Besar sampel dan Cara pengambilan sampel, Jakarta: Salemba Medika, 2009.

[8] Notoatmodjo, Ilmu Perilaku Kesehatan, Rineka Cipta, 2010.

[9] R. W. Wisnuwardani, "Insentif Uang Tunai dan Peningkatan Kinerja Kader Posyandu Cash Insentive and Posyandu Cadre Increasing Performance," p. 44-48, 2010.

[10] W. Sukrayasa and E. Martiningsih, "Strategi Pemberdayaan Kader Posyandu untuk Meningkatkan Program Gizi di Kecamatan Denpasar Utara," Journal Ilmu Gizi J. Nutr. Sci, vol. 7, no. 2, p. 42-48, 2018.

[11] Kemenkes RI, "Kader Posyandu: Peranan Dan Tantangan Pemberdayaannya Dalam Usaha Peningkatan Gizi Anak Di Indonesia," J. Manaj Pelayanan Kesehat, vol. 13, no. 4, p. 1-53, 2014.

[12] S. Notoatmodjo, Promosi Kesehatan dan Ilmu Kesehatan, 2020.

[13] F. Kusyanti, "the Relationship Between Mother Knowledge Level of Posyandu With Mother Obedience Coming To Posyandu in Mayungsari Village Bener Purworejo," vol. X, p. 85-94, 2015.

[14] W. Subagyo and D. Wahyuningsih, "Peran Kader Dalam Memotivasi Ibu Balita Berkunjung Ke Posyandu," Soedirman Jurnal Nurse, vol. 10, no. 3, p. 158-166, 2015.

[15] S. M. Triyanti and L. Widagdo, "Peningkatan Pengetahuan dan Ketrampilan Kader Pemantauan Tumbuh Kembang Balita di Posyandu dengan Metode BBM dan Mind Mapping (MM) Mimin," Jurnal Promosi Kesehatan Indonesia, vol. 12, no. 2, 2017.

[16] M. Francesconi and J. J. Heckman, "Child Development and Parental Investment: Introduction," Econ Journal, vol. 126, no. 596, pp. F1-F27, 2016.

[17] Kementrian Kesehatan RI, BUKU KESEHATAN IBU DAN ANAK, 2016.

[18] A. H. Wahyutomo, "KEMBANG BALITA DI PUSKESMAS KALITIDU-BOJONEGORO," p. 1103, 2010.

[19] M. D. Onis, Nutrition and Health in Developing Countries Second Edition\& Wolfman, Totowa, NJ 07512 USA): Humana Press, 2017. 